\title{
Chapter One: \\ Simplicity by Necessity and Choice
}

\section{The Austere Model of Dress}

If asked nowadays about dress in the 1950s, most Israelis, whether born before 1949 or after 1956, would probably reply that the period was marked by stark simplicity. In Israeli collective memory, the 1950s are visually associated with the figure of "Srulik," a local icon created by cartoonist Dosh (Kariel Gardosh, 1921-2000). Srulik, like British John Bull and American Uncle Sam, served as a symbol of the modern state. A young innocent boy, Srulik wore shorts, a simply cut shirt, high working shoes or sandals, and the floppy "tembel" hat. Although Srulik received his name and his final shape only in late 1956, earlier versions of his image had been drawn by Dosh since the early 1950s. ${ }^{1}$

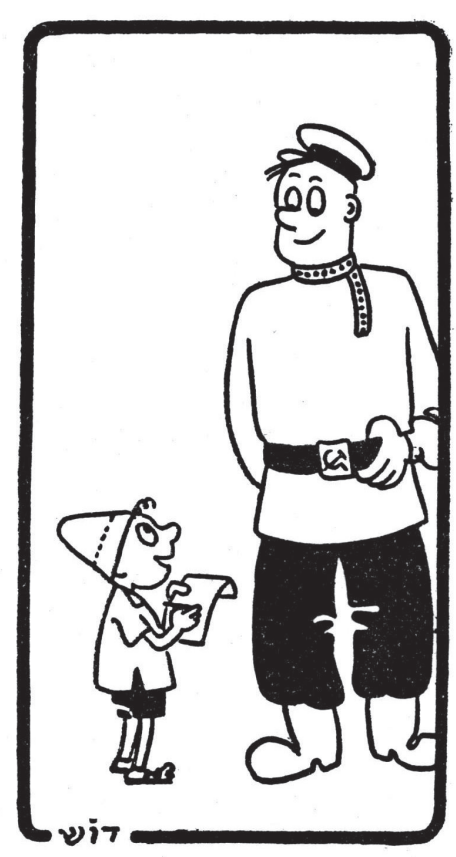

Figure 1.1: Trade negotiation between the USSR and Israel in January 1954. Srulik is saying: "We need fuel, timber - and two million Jews." Dosh portrayed both states by using their "typical" dress.

From Dosh (1956), 49. Courtesy of the Gardosh family. 
Srulik's outfit represents a common sartorial style in 1950s Israel. The main feature of this Israeli austere model of dress ${ }^{2}$ was a combination of long or short cotton pants, mainly dark blue or khaki, with a cotton shirt or chemise. The shirt, as a local fashion reporter mentioned in 1956, was the most popular dress in Israel, and "has become our classic clothing item." Men's shirts had long sleeves, which were rolled up in summer. Women wore various designs of simply-cut chemises. Khaki was the dominant color in men's clothes, but later they also wore checkered flannel shirts. In winter both men and women added a jumper or a buttoned knit sweater over this basic combination. Men wore simple loose jackets that could warm them without hindering their informal appearance. Both men and women wore the plain double-striped sandals in summer and flat and solid black or brown shoes in winter. The austere model demanded clean abundant hair in unfussy hairstyles: the men wore their hair short with a prominent forelock; women either cut their hair to neck or shoulder length, or kept their long hair tied or braided. ${ }^{3}$

Placed at the highest point of the body and framing the human face, head covers are particularly conspicuous items of dress. In addition to their practical role of protecting the head, headdresses can signal status, lifestyle, and religious or political affiliations concisely and clearly. ${ }^{4}$ Male pioneers from the founding Yishuv generation often covered their heads with a Russian peaked cap made of felt. This item, imported to Palestine with Zionist immigrants since the Ottoman period, signified their socialist ideals, because such caps, "casquettes," became the emblem of male workers in Europe and had been a recognizable visual political statement of class since the late nineteenth century. ${ }^{5}$

Another prominent hat in the austere model was the tembel hatthat floppy bell-shaped cotton cap worn by Srulik. The word "tembel" means "stupid" in Hebrew slang. ${ }^{6}$ The tembel hat has been worn since the 1920s by agricultural workers, road constructers, and builders. Its origin is unknown. Some argue that it was a Templar cap, ${ }^{7}$ imitated by the Jewish pioneers, its name changing from "Templar" to "tembel"; others argue that the name derives from the Turkish word "tembel"-meaning "lazy"-an ironic description of the training pioneers who wore it in the 1920s. ${ }^{8}$ The tembel hat, usually khaki or dark blue, was worn in the 1950 s by many Israeli natives, members of youth movements and kibbutzim, as well as soldiers in the army reserve forces. Since the second half of the decade-partly due to Srulik's image-the tembel hat won 
an iconic status as a symbol of Israeli culture. ${ }^{9}$ Tembel hats were sometimes worn by young women as well as by men, whereas other women clad in the austere model covered their heads with a kerchief, or-in the case of young women-with an Arab kafiya. ${ }^{10}$

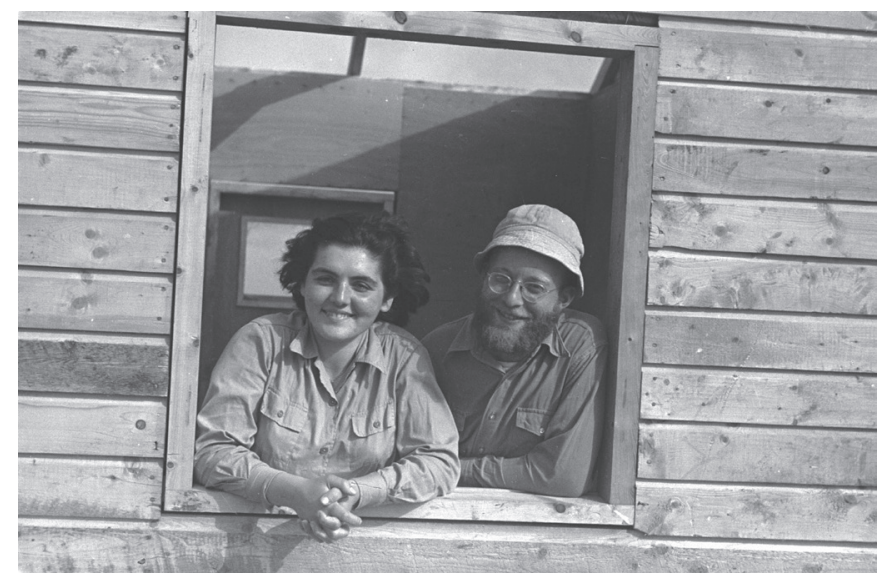

Figure 1.2: Members of a religious Zionist new settlement, Bnei-Darom, in 1949. Both settlers are wearing the unisex working shirts and the man-a new immigrant from the United States - is wearing the tembel hat.

KKL-JNF Photo Archive, d3010-092. Photo by Fred Cheznik.

According to the standards of the austere model of dress, simplicity was maintained on festive occasions, when both men and women wore dark pants with white shirts and chemises. Women sometimes replaced the pants with a dark, straight-line, skirt. Whether it was Independence Day or an international soccer match-the importance of the occasion was declared by the gleaming though simple white tops worn by many participants. The embroidered Russian shirt and the dark sarafan-a sleeveless dress covering a chemise-were popular as festive clothes as well, especially among young people. ${ }^{11}$

A locally famous clothes manufacturer named "Ata" produced quality items according to the austere model's style. Ata was founded in 1934 and by the mid-1950s became the largest textile manufacturer in Israel. Its products were renowned for their simplicity, practicality, high quality, and modest prices. Ata specialized in unadorned daily wear and was famous for items such as khaki shorts, pants for men and women, men's 
shirts, simple-line chemises, working overalls, aprons, casquettes, and tembel hats. Ata also produced dresses, jackets, and coats, but these too maintained a typical unelaborated, somewhat military, cut. ${ }^{12}$ During the rationing regime of the early 1950s, Ata's durable yet cheap products were commended as particularly fitting the circumstances, aesthetically as well as technically. But Ata remained popular in the mid-1950s, even after the rationing was over. Although it specialized in simple casual wear, it continuously renewed its models and maintained the high quality of its products. When its new dresses were presented in a 1954 fashion show in Jerusalem, for example, a fashion reporter stated that "Ata's cheap and pretty dresses deserve to be owned by every woman as her morning outfit."13

"In our country," wrote a local journalist in that same year, "the simplicity of dress has reached dimensions unknown in other countries."14 And indeed, the austere model was casual, informal, seemingly careless, yet clean and not too shabby. It pretended to mark a disregard for appearance. However, let us keep in mind that a defying style, supposedly unheeding to the dictates of fashion, might in fact require a lot of attention. It is not the result of indifference or absent-mindedness, but rather involves awareness and consideration..$^{15}$

The austere model of dress in Israel was a direct continuation of the style sported by the pioneers in the Yishuv era. Fashion historian Ayala Raz describes the development of the pioneers' dress since the beginning of the twentieth century. First, the European fashionable garments brought with the Jewish immigrants to Palestine had to be folded, cut, and adjusted to the hard manual labors carried by the pioneers. Gradually, female pioneers adopted men's items such as pants and peak caps, and some cut their hair short, years before short hair became a 1920s women's fashion. Among male pioneers, the Russian folk shirt (rubash$k a$ ), with its asymmetrical collar and embroidery at the openings, was worn in various shades and manners. Men also signified their absorption into the local land by covering their head with the Arab kafiya. During the 1930s the kafiya was becoming a national Arab symbol, and was therefore abandoned by Jewish pioneers in favor of peak caps and wide-brimmed straw hats. Heavy brown and black working shoes were worn by both men and women in winter, plain double-striped sandals and short pants were worn in summer. In the 1940s men's khaki shorts became very popular for both work and leisure. Since the 1920s, women 
pioneers had adopted the Russian sarafan as their festive dress. ${ }^{16}$

Pioneers' dress had its technical grounds-it suited the local climate, fitted hard manual labor, and could be afforded or hand-made by poor settlers. Still, opting for Russian folk shirts and sarafans even for their leisure wear, rather than following the latest Western fashion, indicates that Zionist pioneers were also using dress in order to visually affirm and manifest their socialist revolutionary ideology. ${ }^{17}$

During the Yishuv era, the pioneering dress was worn specifically by a minority of agricultural and urban pioneers. However, after the foundation of the state, the austere model spread to wider sections of society, especially among Israeli men. It was more common among workers and in agricultural settlements, but the austere model's basic combinations were also often worn by people who lived in cities, worked in whitecollar professions, and had a middle-class lifestyle. Sometimes a single smarter item, such as a tie, was added, and the casquette or tembel hat was replaced by a homburg hat. Although small, these items indicated that the wearer was not adopting the austere model in its entire, extreme form, and identified him as belonging to the middle class. Staunch supporters of the socialist ideology were loath to wear such unmistakably bourgeois hats and ties. ${ }^{18}$

In Israeli imagination and lore, the austere model was primarily associated with the Israeli natives-the "Sabras." From the 1930s, Jewish natives in the Yishuv were nicknamed Sabras, after the fruit of a common local cactus. The title indicated the natives' rough and prickly exterior and their sweet interior. Once the pool of potential new pioneers was eradicated in the Holocaust, the Sabra replaced the pioneer as the ultimate national hero. Moreover, the Sabras' share as fighters in the War of Independence was prominent and culturally stressed, and thereafter they were covered with national feelings of gratitude and admiration. ${ }^{19}$

Sabras (who comprised about a third of the Israeli population ${ }^{20}$ ) were depicted both in formal and in popular culture as markedly different "from other Jewish children" and from newly arrived immigrants. Most of them were described as jovial and laughing, disobedient to their parents and doing as they liked. ${ }^{21}$ Historians and sociologists define the Sabras, who grew up in the Land of Israel in the 1920s and the 1930s, as a generational group with its own specific style. The Sabras could be recognized by their distinct form of speech and their Hebrew accent, 
their special body language and typical dress. The Sabra was perceived as the extreme opposite of the Diaspora old Jew: healthful, brave, active, tough, group-orientated, deeply rooted in his native land, direct, informal, spontaneous, uncomplicated, anti-intellectual, and unostentatious. ${ }^{22}$ It is therefore no wonder that Srulik, the cartoon incarnation of the state of Israel, was depicted in the shape of an archetypical Sabra.

Israel's sub-tropical Mediteranean climate probably contributed to the informal attitude in dress and encouraged the preference for the austere model. In august 1949, when temperatures in Tel Aviv reached over 40 degrees Celsius (104 Farenheit), the street was described as taken over by khaki: "Even distinguished citizens, professors and doctors, who often dress up in formal evening suits, do not shun nowadays from wearing the austerity dress-khaki shorts." ${ }^{23}$ Yet the widespread popularity of the austere model of dress in the 1950s was probably interrelated first and foremost with economic circumstances-the meagerness of recources in post-war Israel-and with the ideological values of the national Centralist ethos.

\section{Simplicity by Necessity: Post-War Rationing}

Textile was one of the Yishuv's main industries and it flourished during World War II. During the first years of statehood, however, the Israeli textile industry faced a rapidly growing demand on the one hand (due to the spectacular growth of Israel's population), and an acute shortage of basic raw materials and necessary equipment, on the other. The need to supply cheap clothing hurriedly and under restricted conditionsimported materials and goods were strictly restricted and supervisedmeant that the quality of products deteriorated sharply. ${ }^{24}$

In January 1949 the Israeli government launched a local program for manufacturing cheap clothes and shoes. These subsidized products, titled Lakol ("for all"), were at least 30 percent cheaper than equivalent products sold in the free market. Lakol was supposed to continue the success of the local Utility program, implemented in Palestine by the British government during World War II. In Britain itself, the subsidized and supervised items of Utility had been manufactured since 1941 and during all the years of austerity, until the program was finally cancelled in 1952. Designed by the best British stylists, Utility products were quite popular in Britain, even as late as $1950 .{ }^{25}$ The Utility program in 
Palestine, running from 1942 until 1946, eventually covered 80 percent of all locally manufactured clothing, and it too provided consumers with cheaper, yet reasonably satisfying and fashionable, shoes and clothes. ${ }^{26}$

The Israeli Lakol program, however, was neither as successful nor as popular as its predecessor. Lakol items were of poor quality, limited by a restricted amount of fabric per item, and stylistically resembled the Utility designs. The latter were in vogue in the mid-1940s but totally out of fashion by the end of the decade. Thus, in spite of Lakol's low prices, Israeli women preferred paying higher prices for better, unsupervised, items. ${ }^{27}$ The Lakol program was promoted vigorously by the government and reluctant merchants were ordered to present unattractive Lakol products in their shop windows. Still consumers were unconvinced. The unpopularity of Lakol products was reflected in contemporary slang: unattractive girls were described in the terms "austerity face" and " $\mathrm{La}$ kol figure." 28 Even staunch supporters of simplicity, like the editor of a left-wing women's bulletin, voiced their discontent: a woman can't find nowadays, she complained, a proper Lakol dress made of good fabric or designed in good taste. ${ }^{29}$

The deterioration of locally made clothes was part of a much wider economic plight. Post-war Israel faced serious economic challenges: the war affected local production and cut the young state off from its neighboring Arab markets, while the absorption of mass immigration put huge pressure on the country's limited resources. In April 1949 the Israeli government launched an austerity policy ("Tzena"). Rationing was one of many intervening economic steps taken by the centralist government, led by the Mapai labor party. It was influenced by centralist economic policies, embraced at that time by many post-war European countries. The austerity policy also leaned on local precedents: rationing was declared by the British government during World War II, and later by the sovereign Israeli state during the War of Independence. The austerity policy was meant to decrease consumption, increase production, and ensure the supply of vital products, especially food, to the entire population - including needy new immigrants. ${ }^{30}$

At first the austerity policy was accepted willingly by the Israeli public, who viewed it as a necessary step, as a temporary and inevitable restriction of consumption, and as a means of achieving important national goals in the long run. However, the policy gradually met with growing objection and discontent. ${ }^{31}$ In her research on austerity in Is- 
rael, historian Orit Rozin describes how during its first nine months food rationing seemed successful, but by January 1950 the government was struggling to supply sufficient quantities of protein and began to cut down ration sizes. Black market activities were on the increase and the government reacted by stricter enforcement, intrusive inspections, and invasive supervision. But to no avail: the system was eroded by the consumers' noncompliance. ${ }^{32}$

Rationing usually focuses on the most vital product-food, ${ }^{33}$ and the Israeli austerity policy, too, started with the rationing of food and raw materials. But in July 1950, more than a year after the launch of food rationing, the Israeli government published its decision to ration clothes and footwear as well. ${ }^{34}$ Each item received a certain point value, according to the price of the imported materials required for its production. Due to local shortage of raw materials, deficient foreign currency, and insufficient production by the local industry, the government could assign only a small portion for each citizen. It allocated 100 annual points for clothes and 50 points for shoes, enabling the purchase of few basic products. Men, for example, could afford to buy with their annual portion a short wool coat, short khaki pants, a khaki shirt, underwear, and a pair of cotton socks; women could purchase a short coat, a cotton skirt, a cotton dress, a viscose blouse, synthetic stockings, and a pair of socks. Choosing to follow the British coupon-points system permitted Israelis some flexibility. They could save their clothing points in order to buy a costlier product, and use their clothing coupons in any shop they chose. Food purchase, in comparison, was much more rigid: food coupons referred to specific products and could be used only in the consumer's local store. ${ }^{35}$

When the austerity policy was launched, a special "Rationing and Supply" office was founded, headed by Dr. Dov (Josef) Yosef (18991980). ${ }^{36}$ After clothes were added to the rationed products in July 1950, Dov Yosef gave a speech on national radio (television broadcasting began in Israel only in the late 1960s, so radio played a central role during the state's first two decades ${ }^{37}$ ). In his speech, the Minister explained that rationing was the only way to prevent injustice and want; just as food rationing secured a portion of food for every citizen, so would the rationing of shoes and clothes guarantee that all Israelis get their fair share of these vital products. The Israeli public, said the minister, must realize that: 
We cannot afford to keep on living without accounting and without self limitation. Due to the shortage of foreign currency we have no choice but to adjust to a wider and stricter austerity regime.

Local industry and agriculture would gradually develop and free Israel from its need to import ready-made clothes and raw materials, such as cotton and wool. These steps, said Yosef, as well as increased export, would eventually bring about prosperity, but in the meantime the public must be patient and endure the inevitable restrictions. ${ }^{38}$

The austerity policy was described by the government as a continuation of the War of Independence: in order to build the state and secure the peace, the national economy must be stabilized and therefore citizens should comply and sacrifice their personal comfort. ${ }^{39}$ Yet in spite of preparations, promotions, and lofty rhetoric, the public response to the rationing of clothes and shoes was extremely negative. By the time Dov Yosef presented the clothes and shoes rationing decree, more than a year after the introduction of food rationing, many Israeli consumers were already hostile toward the rationing policy, or at least toward the manner in which it was implemented in practice. ${ }^{40}$

The rationing of clothes and shoes overthrew the last remnants of public trust in the government's economic control. Therefore when the forthcoming decree was announced, consumers flooded the shops and hoarded stocks, especially items that they feared would soon disappear, such as nylon stockings. In fact the public started buying clothes as soon as the plan to ration clothes was first rumored in the spring of 1949. The government promised reduced prices and asked the public to wait and refrain from panicked purchase for overcharged prices, but in vain: after experiencing food shortages, Israeli consumers mistrusted the government and did not heed its calming declarations. ${ }^{41}$ Traders, who from the earliest days of rationing became the main target of consumers' angers and frustrations, headed the objection to the rationing of clothes and shoes. The decree forced them to sell their wares only for coupons, and their stock could be renewed only after all consumers' coupons were checked. When the decree was first announced, traders of clothes and shoes launched a general protest strike and closed down their shops. ${ }^{42}$

Surprised by this harsh reaction, the government established a spe- 
cial committee to investigate the new rationing decree. Following the committee's conclusions, the government increased the ration size. A revised and more detailed decree was published, with updated lists of products, points, and prices. The Ministry of Rationing and Supply also made some concessions to the original decree: additional points were allocated to pregnant women and babies, veteran soldiers and war casualties, to the sick and the disabled. ${ }^{43}$

Whereas food rationing was first accepted by the general public as the inevitable need of the hour, the rationing of clothes was received ambivalently and unfavorably from its very announcement in July 1950. The difference lies partly in the rationed product itself. A certain amount of food, with a specific nutrition value, is considered a universal and measurable essential need that must be distributed in times of emergency among the population. Needs of dress, on the other hand, are perceived as more relative, changeable, and subjective. The editor of a women's journal, for instance, wrote that the new decree puts even the supporters of rationing in "an emotional and economic dilemma." She objected to an equal distribution of points, claiming that unlike food, needs in dress may vary according to class, profession, and location. Under such a restraining decree even law-abiding citizens, she insinuated, might resort to buying their clothes in the black market. ${ }^{44}$ Indeed, some Israeli consumers reacted to rationing simply by breaking the law and buying goods in the growing black market. The black market might undermine the whole rationing system, and could serve as an indication of consumers' compliance. Alongside formal denouncements of the black market and its profiteers, in practice it continuously grew and expanded. ${ }^{45}$

In order to enforce the rationing decree, producers, merchants, and consumers were all inspected. The ministry's supervisors were authorized to interrogate anyone, to conduct searches, and to confiscate material evidence. Policemen made sudden inspections in shops, buses, and even in the consumers' homes, to check whether shop owners sold their merchandise only according to the law-namely for rationed points and after checking the buyers' identities - and whether consumers exchanged their purchase for the proper coupons, as requested by law. Supervisors seized illegal raw materials (fabrics, strings) and clothing items that were sold illegally in the black market. Yet transgressions were still on the increase. ${ }^{46}$

The Ministry of Rationing and Supply also founded a special branch 
to address complaints. Citizens expressed their personal opinions about the rationing system and sent the ministry suggestions and advice. Many writers asked for special permits and extra points, detailing their specific circumstances and needs. Among them were war veterans, who after long years of army service had been left with no civilian clothes; reserve soldiers who ruined their last civilian dress in military training; civilians whose wardrobes were destroyed during the war; manual workers whose jobs required special clothing; young couples about to get married and new immigrants, who described their troubles in broken Hebrew. ${ }^{47}$

Such letters exemplify the sartorial plight of many Israelis during the first years of statehood. A veteran soldier, who was wounded and hospitalized for a whole year, had gained twenty kilos in hospital and so he couldn't put on the Utility suit he had received five years earlier, and his three-year-old shoes were torn. Another veteran described his entire wardrobe as containing two pairs of khaki pants, two khaki shirts, two white shirts, one pair of wool pants, and no winter clothes whatsoever. ${ }^{48} \mathrm{~A}$ clerk in a government office wrote that her summer shoes had been torn for the last four years, and that the shoe-mender can mend them no longer; she must therefore wear her heavy winter shoes in summer as well. Out of the four summer dresses she owns, two are torn beyond repair. She couldn't afford a winter dress and has been wearing only skirts and sweaters during the past few winters. Her bosses and colleagues at work, she wrote, can attest to her difficult situation. Now, after she has finally managed to save enough money to buy two summer dresses, summer shoes, and some fabric for sewing a winter dress, she is restricted by the new rationing regulations. She therefore requested a special permission from the Ministry of Rationing and Supply to purchase these items, and "since I renew my wardrobe only once in three years, I believe it is not an exaggerated request." ${ }^{49}$

Rationing affected marketing and advertising too. In a time of set prices, no special sales could be held. During the rationing period many ads stressed the relevant virtues of the product, namely its cheap price and availability. Advertisers called on consumers to show good judgment and frugality in their choice. ${ }^{50}$ In July 1950, an ad published in the daily newspaper The Jerusalem Post depicted three items of clothing emerging from a rations coupon-book. Matzkin, a successful local manufacturer, promised its clients full value for their new rationed points. ${ }^{51}$ 


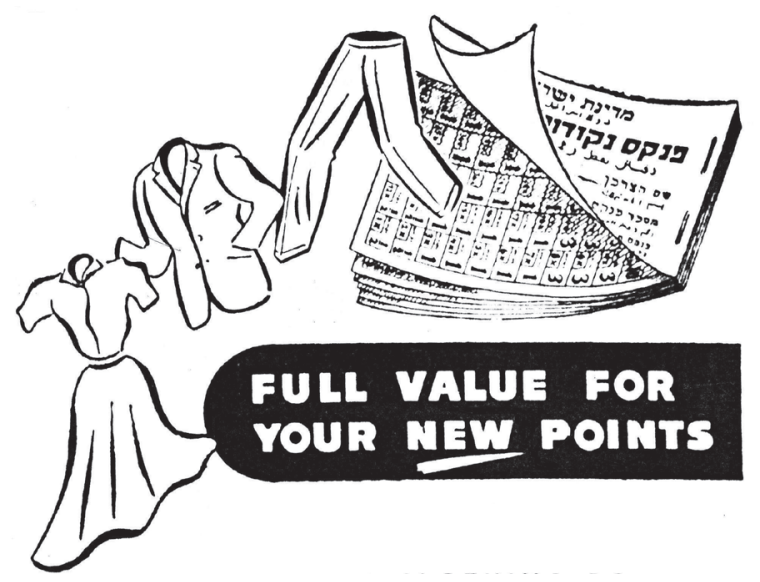

Figure 1.3: Matzkin ad in The Jerusalem Post, July 5, 1951.

A prominent men's clothes firm even promised to save its clients from one of rationing's annoying side-effects, the inconvenience of waiting in long queues, ${ }^{52}$ but a photo taken in one of its branches only one month earlier provides a contradictory picture:

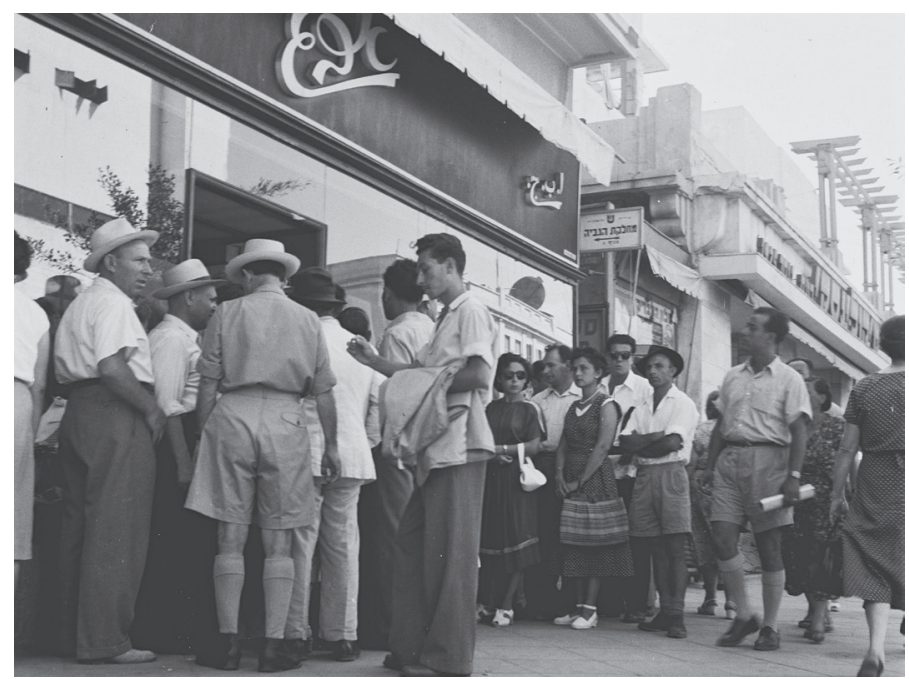

Figure 1.4: Customers waiting at the entrance of the OBG clothes shop branch in Tel Aviv in July 1951.

Government Press Office, NPC, D720-091. Photo by Hans Pinn. 
Indeed, Rozin mentions that the flaws that characterized food rationing were also apparent in the rationing of clothes. The dire shortage of raw materials and products meant that even basic items were hard to find, long queues were gathering before the entrances of the shops, and the quality of available products was deteriorating. ${ }^{53}$ Cheap daily clothing items, such as working garments or warm tops, were hard to find, whereas luxury items, such as evening gowns or imported hats, could be purchased for a tiny amount of ration points but for astronomical prices, affordable only by the richest. ${ }^{54}$

Humor, as Rozin mentions, was one of the ways by which Israeli society dealt with the hardships of rationing, a safety valve into which consumers could channel some of their frustrations. ${ }^{55}$ Comic aspects of the grim economic situation were often formed into written satire, verbal jokes, and cartoons. ${ }^{56}$ When clothes rationing was introduced, a cartoon portrayed the stage scene from Shakespeare's Othello when he demands his wife show him the incriminating handkerchief. "Slow now, my friend," replies the fair Desdemona, "Do you have the necessary points?"57 Another cartoon predicted the use of newspaper-hats as actual head-covers for an entire family. ${ }^{58}$

In the national folk-dance festival of 1951, one dancing troupe performed a dance titled "Rationing," in which each dancer wore only one boot. ${ }^{59}$ A woman from Tel Aviv related how a man whispered to her on the street, "Excuse me, Madam, but your seven points is showing." Seven was the number of points allocated for an imported poplin bra ${ }^{60}$ Some jokes focused on specific aspects of rationing, for example consumers' dependence on scarce rationed points:

Uri and Yonatan meet in the street. "Why are you walking in these huge strides?” asked Uri.

"Because I don't have enough points to buy new shoes, and I am trying to save the soles," replied Yonatan.

Two weeks later they met again. "What happened to you," asked Uri, "and why have you suddenly decreased your stride?"

"When I used big strides my pants were torn," replied Yonatan, "and I have no points to buy new pants." ${ }^{1}$

Sarcastic descriptions of the scarcity of clothes were even heard in the 
Israeli parliament and its committees. When the head of the right wing opposition party Herut attacked the kibbutzim in one of his speeches, Prime Minister Ben-Gurion replied: "Put off thy shoes from thy feet when you speak of the kibbutzim" (namely: show them some respect). A female member of Herut then retorted that "Due to the rationing of clothes and shoes, we are left shoeless as it is." ${ }^{2}$ Her response literalized the biblical expression and used the unpopular decree to attack Mapai's centralized economic policy.

Ironic presentations of rationing could sometimes be seen in shop windows: A shoe shop window with signs that supposedly hailed Dov Yosef in late 1949, or naked mannequins wearing only fig leaves when the rationing of clothes was introduced in the following year. ${ }^{63}$

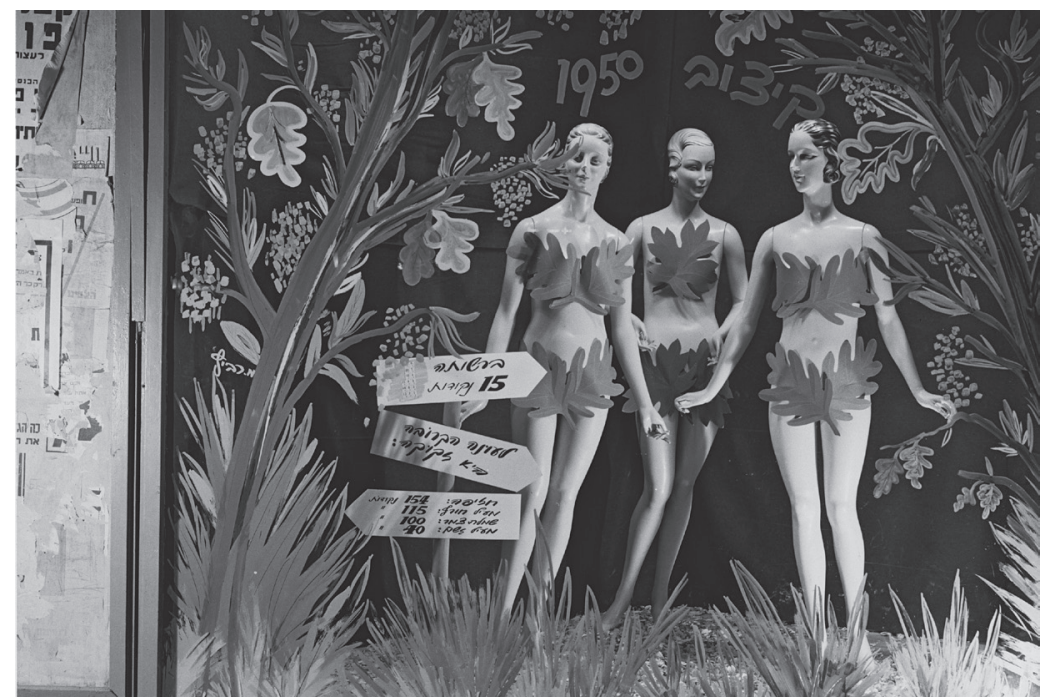

Figure 1.5: Shop window display in Tel Aviv, April 1950.

Government Press Office, NPC, D720-101. Photo by Hans Pinn.

Humor could help consumers face their plight, but it could not improve their economic conditions. By July 1952, two years after the introduction of clothes rationing, the local dress market reached an unprecedented depression. Prices of quality items in the free market were much too high for the average consumer, and, on the other hand, consumers refused to buy rationed items, which were cheap but of dreadful quality. In late 1952, when the turnover in the clothing trade reached a 
new low, and as the national economic policy was changing, it was decided to remove rationing gradually from dress items, until the cancellation of the points system in early $1953 .{ }^{64}$

When rationing was cancelled, Israelis noticed the reappearance of abundant and various supplies that had vanished during the last couple of years, but in practice consumers still struggled to obtain textile products. A left wing journalist wrote that:

Different kinds of fabrics suddenly appeared in the shops: wool, linen, silk, curtains, upholstery materials of all colors and sorts, things that have not been seen in the shops for years.

However, she added, although the shelves and shop windows are filled with goods, people have no money and the prices are so very high. How can one buy a sweater, a coat, a curtain, or a summer dress, when the provider of the family is unemployed or hardly earns enough to buy food and pay the taxes? "Women stand in the street and talk in front of the shop windows: everything is here-they say-but for whom?"65

Yet by 1954 Israel was starting to recover from its economic crisis and the economic growth was clearly felt by consumers, as both supply and purchasing power increased. Once controlled prices were removed, producers and merchants started to compete, and consumers enjoyed reduced prices. During the years of rationing consumers were totally dependent on suppliers, but now the tables were turned: now suppliers had to persuade their customers and vendors had to show them more courtesy (the latter was a rare virtue in Israeli culture ${ }^{66}$ ). As the quality of clothes and shoes improved, consumers "realized with what inferior quality we had been 'fed' during the Yosef era." Soon the days of rationing were depicted as a gloomy chapter from the past and compared unfavorably with the happier present. ${ }^{67}$

The shortcomings and widespread unpopularity of the rationing regime notwithstanding, we should not lose sight of its primary purpose: to ensure that even the neediest Israelis were minimally clothed. Prime Minister Ben-Gurion clarified that although social equality was a noble goal, the rationing in Israel did not intend to impose equality, but rather to ensure that all citizens were supplied with essentials. ${ }^{68}$ The rationing policy equalized Israeli society more than ever before or after, ${ }^{69}$ but it 
preserved and even fortified the line between the upper middle class and the majority of the population. Clothes rationing hardly affected the richest population, who was better equipped in the first place and could also afford to pay the astronomical prices for un-rationed high quality clothes. Less wealthy Israelis and the poor, who had fewer shoes and clothes to begin with, were dependent on their rationed coupons and could afford only low quality rationed products.

So while it lasted, austerity affected Israeli dress materially and technically, because it limited and even dictated what many Israelis could actually wear. On a moral level, rationing also justified and supported the austere model of dress as part of a general frugal lifestyle. Luxuries had been frowned upon since the Yishuv era, because they seemed to contradict and subvert the dominant ideal of pioneering. Rozin maintains that the Israeli rationing policy was not meant to enhance ascetic lifestyles, but was rather chosen for practical reasons, mainly the absorption of the great aliyah. Moreover, one of the goals of austerity was to allow future economic growth. Still, once implemented, the policy was also described as "proper" in moral terms. ${ }^{70}$ Whether ascetic ideals were truly adopted by Israelis or not, they were often evoked in support of the austerity policy and the public was called to avoid any waste and luxuries. "Excessive extravagance" in dress was rebuked as unsuitable for "these times," not only because it hindered economic recovery, but also because it reflected and visibly displayed inequalities within a State that tried to promote civil solidarity. ${ }^{71}$ Thus even Israelis who were not severely restricted by economic circumstances, sometimes opted for the austere model of dress on ideological grounds, because it reflected the county's dominant value system.

\section{Simplicity by Choice: The Centralist Ethos}

Israel's centralist ethos was consolidated and championed by Prime Minister David Ben-Gurion. The Hebrew word coined by Ben-Gurion, "mamlakhtiyut," was probably inspired by a similar Russian notion and cannot be translated accurately into English. ${ }^{72}$ Unlike "Statism," a notion indicating centralized state institutions and policy, Ben-Gurion's centralism stressed the civil obligation to the state. It was meant to draw respect towards the authority of the state and its laws, to excite Israelis with a feeling of public commitment, and to unify the nation. 
Ben-Gurion regarded the state as the only political and symbolic factor that could bond together the fragmented Jewish people. He wished to consolidate the new Israeli nationality, its collectivity and solidarity, around the state. From its onset the Zionist movement aimed to create a strong, brave, and active "new Jew," the utter opposite of the stereotypical weak and passive "old Jew" of the Diaspora (the latter's image was clearly influenced by anti-Semitic notions). Ben-Gurion viewed the new sovereign state of Israel as the tool that could and should build the new Jews-free and upright Israelis. The centralist ethos was intended to constitute a novel Hebrew character and to shape the mass of new immigrants, described by Ben-Gurion as "human dust," into proper Israelis. ${ }^{73}$

Another goal of the centralist ethos was to unite long-time Israelis as well. Although sharing a comprehensive Zionist ideology, Yishuv society was marked by political factionalism and organizational fragmentation. After the foundation of Israel, various sub-centers were required to surrender their former roles to the state. Ben-Gurion saw state building as a replacement of pre-state Zionist institutions and identifications. Thus the centralist ethos helped to re-shape Yishuv society. The state, governed by Ben-Gurion's labor party Mapai, held a centralized policy in practice (Statism); but rather than relying solely on enforcement, citizens were also being persuaded about the primacy of the state. State institutions, the educational system, the media, the intellectual elite, and other factors and agencies, all worked to convince Israelis that they should transfer their loyalty onto the state and cooperate willingly with its demands. ${ }^{74}$ Ben-Gurion's centralism managed to unite society and solidify the authority of the state. Even factions that strongly opposed Mapai on political and partisan levels accepted the primacy of the state and the importance of national unity. In spite of some religious, ethnic, and political rifts, the first years of the state were marked by political stability. ${ }^{75}$

Centralism was supposed to play yet another national role-to incite a disciplined voluntarism among all Israeli citizens. ${ }^{76}$ In this respect, the Israeli centralist ethos was a modified version of the former pioneering ideology that reflected the values of Socialist Zionism and eventually became the dominant ideal in the Yishuv. During the prestate era, only a minority of Jewish immigrants actually fulfilled the ultimate pioneering ideal, settling in agricultural frontiers and sacri- 
ficing their personal comfort and well-being for the sake of building a just society and a future national home. Yet the entire Yishuv, including the majority of Zionists who settled in towns and cities and led a middle-class lifestyle, acknowledged the pioneers' important contribution to the nation. The pioneers were widely regarded as the Yishuv's true elite. ${ }^{77}$ After the foundation of the state, the centralist ethos was supposed to replace the Yishuv pioneering ideology and, furthermore, to extend it unto the entire Israeli population. Agriculture and manual labor were still viewed as vital for developing the land, but now BenGurion broadened the notion of "pioneering" to envelop all sections of society and to cover whatever mission, task, or occupation could benefit the state. Ben-Gurion wanted to subordinate and centralize the voluntary spirit of the pre-state era; the Yishuv avant-garde revolutionary pioneer was now to be replaced by an obedient pioneer, who would serve the state dutifully. ${ }^{78}$

Interestingly, the centralist ethos was in fact an attempt to counter an actual relaxation and dwindling of the Yishuv's pioneering spirit. The main pool of potential pioneers-young East European socialists-was wiped out in the Holocaust. After 1948, many new immigrants did not adopt the collective message of the centralist ethos, because it did not coincide with their original cultures. Former pioneers and Israeli natives were exhausted after years of national struggle and a total war. Many long-time Israelis-even those who supported BenGurion, Mapai, and the centralist ethos politically and ideologicallywere gradually enjoying a higher standard of living and moving upward in the occupational scale, while new immigrants replaced them as the new working class. All in all, pioneering seemed to have lost some of its former "trendy" appeal; the sacrificing facet of the centralist ethos remained mainly ideological, and was translated into actual behavior only in part. Ben-Gurion and other leaders were bitterly disappointed and frustrated by the decline of the pioneering spirit in Israel. Between late 1953 and early 1955, Ben-Gurion withdrew from politics and lived in a new kibbutz in the Negev desert, where he worked, at least part time, as a shepherd. But even his personal example was not followed by the masses. ${ }^{79}$ 


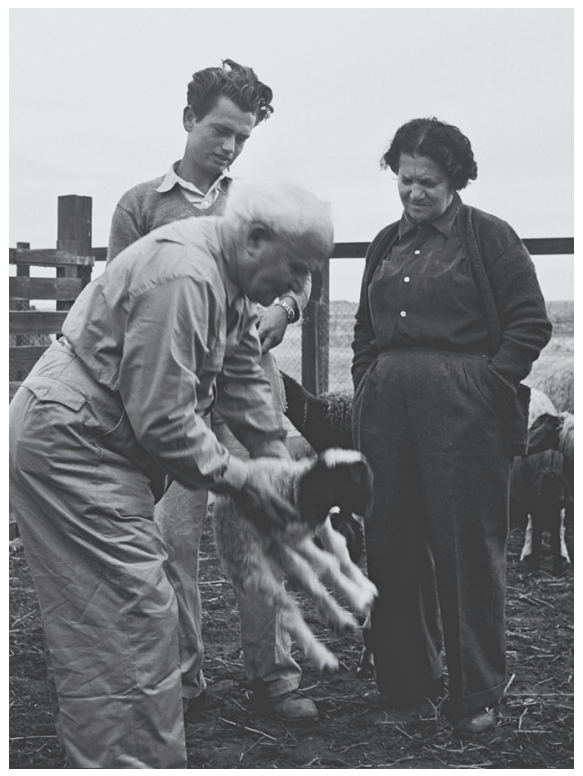

Figure 1.6: David Ben Gurion working in Kibbutz Sde Boker, 1954.

Government Press Office, NPC, D683-042. Photo by Fritz Cohen.

Though not implemented in practice by most Israelis, the centralist ethos did manage to win general public agreement and thus achieve a hegemonic status on the ideological level. Hegemony is a wide agreement and a general support of the existing order, implemented by the ruling elite in society at large. Parliamentary regimes do not have to rely on the state apparatuses of force, as long as the ruling group achieves moral authority and public legitimacy. Rather than applying enforcement or oppression, the ruling group can lean on its economic power and spread its own definition of reality among all other groups in society. The latter are convinced and hence they adopt the ideology — which actually represents the interests of the ruling group-as the "natural" and permanent order of things. Hegemony is spread by various agents such as the family, the educational system, the media, and cultural and religious institutions. It is dependent on successful persuasion; hence, in order to gain public legitimacy and secure it, the hegemonic system must adjust itself to constant change and must alter dynamically and pragmatically. Only when hegemony crumbles and public agreement is lost, does the parliamentary regime resort to the use of force. ${ }^{80}$

Israel's hegemonic ethos was expressed, among other ways, in dress. 
Tying any certain manner of clothing to hegemonic values is based on the assumption that people try to act-and dress-according to their chosen ethos. Unlike rooted automatic behavior, a willed and conscious act is conceived by the performer as ethical and moral. Personal action is not meant just to impress others, but also serves as a self-justification. Even when people don't put too much effort into fulfilling their ideology in their personal lives, they do nonetheless attempt to act, every now and then, in a manner that confirms their ethical worth. Thus, in addition to their practical facet and their social role, clothes can also serve to justify and strengthen the wearer's ideological self-image. ${ }^{81}$ Israelis' choice of the austere model of dress could therefore serve to signal both their social and political leanings to observers, and at the same time to assure themselves of their ideological commitment.

Like other national movements, Zionism adopted classical standards of beauty, and the "New Hebrew" was therefore supposed to be the total opposite of the stereotypical "Old Jew" of the Diaspora in his looks, as well as in his mentality and his lifestyle. If, for instance, the old Jew was usually depicted as white-skinned and pale, then the new Hebrew was deeply suntanned. ${ }^{82}$ Sociologist $\mathrm{Oz}$ Almog claims that the Sabra was commonly described as handsome according to classical, European notions: tall, thin but muscular, strong, fair (rather than dark), with a straight nose (rather than the stereotypically long Jewish nose). Almog also notes that this prevailing image was based on certain facts: Sabras' bodies and looks-especially those who were raised in agricultural settlements-were truly affected by a different climate, by physical activity from childhood, and by a healthier diet. Almog also mentions the thick forelock as one of the ideal Sabra's main attributes. He argues that wearing the hair loose and long was a reaction both to the old Jew and his religious head-cover, and to the tidy hairdo of the decadent Western bourgeois. The new Jew's hair, like the biblical examples of Samson and David, indicated his freedom, his new openness to the world, and his connection to nature. ${ }^{83}$

The austere model upheld the Zionist and centralist aspiration of creating a new Jew by negating visually the look of the old traditional Diaspora Jew. Rather than covering the body and hiding it, as was customary among ultra-Orthodox Jews, the loose and bare austere model emphasized the body. Socialist Zionists also objected to the lifestyle of cosmopolitan assimilating urban Jews, ${ }^{84}$ and indeed the simple and in- 
formal austere model of dress contradicted the ostentatious bourgeois style of dress. The comfortable austere model enabled free movement, unlike the physical restrictions imposed both by the long and thick garments of the traditional old Jew, and by the strictly-cut contours of the bourgeois suit. Hence the austere model propagated the merits of the new Jews - it exhibited their healthful, upright bodies, intended for active, bold tasks.

Like the pioneering style which preceded it, the austere model of dress in 1950s Israel can be viewed as an "anti-fashion" that reflected the values of simplicity, equality, labor, and settlement. Anti-fashion involves awareness and alert response to fashion. Clothes that intentionally contradict fashion derive their meaning only from their apposition to prevailing aesthetics, dictated by fashion. Any "alternative" style of dress poses an alternative to the dominant style and is often connected to an entire lifestyle. Anti-fashion is therefore not indifference toward fashion, but rather an intentional and active reaction to it. Unlike individuals who dress unconventionally for various personal reasons, group anti-fashion occurs when members of a subculture, sharing the same political, social, or other agenda, choose to dress in a particular manner in order to embody and symbolize their goals. ${ }^{85}$ If fashionable urban dress mirrored ideals of gentlemanly leisure, then the Israeli austere anti-fashion hailed the value of active, manual, work. ${ }^{86}$

Zionism placed the hard-working pioneer on top of its national scale. Although most Jewish immigrants settled in cities and towns and many maintained middle-class lifestyles, Zionist ideology regarded manual labor-agricultural work in particular-as the summit of the national revival in the land of Israel. Thus, during the Yishuv era, working clothes assumed a special cultural position: they testified to a low economic income but at the same time signified a high social status. ${ }^{87}$ After the foundation of the state, Israeli citizens were called to continue the project begun by the pioneers. Working clothes were a visible indication of fulfilling the centralist ethos by literally building the young state. Central items of the austere model of dress-khaki pants, high shoes, tembel hats-were worn by actual manual laborers, and the latter's husky images were celebrated as a towering national icon in posters and ads. ${ }^{88}$ 


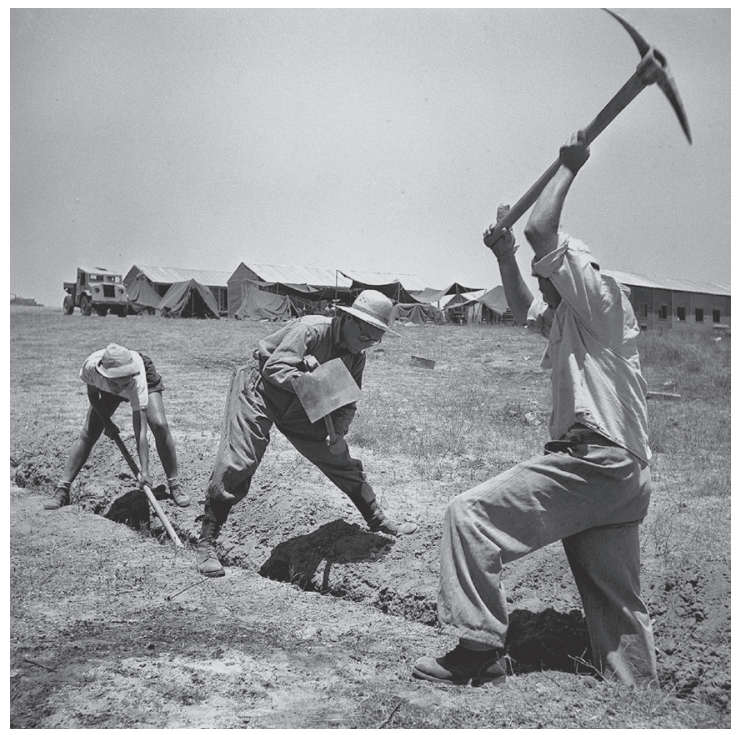

Figure 1.7: Workers laying a water pipe in the Negev, 1949.

Government Press Office, NPC, D592-077. Photo by Zoltan Kluger.

But not just manual laborers, whose physical work demanded freedom of movement, wore simple clothes in 1950s Israel. ${ }^{89}$ Clerks, both male and female, were expected to maintain an unadorned, somewhat informal, style of dress. ${ }^{90}$ When clothes were rationed in the summer of 1950, the workers of the Ministry of Rationing and Supply were required to set a personal example to all Israeli citizens:

Even on special occasions, such as representative meetings etc., there is no need to assume any look of grandeur, and a modest appearance-such as a khaki outfit, an unbuttoned shirt, and no overcoat-would be highly appreciated..$^{91}$

All civil servants were requested that year to "appear at work, and even in parties, with clothes befitting our situation (and no ties!)."92 Secretaries in the private sector were also recommended to maintain a tidy appearance at work, but at the same time to refrain "from a fancy look and from excessive vanity." ${ }^{33}$ The economic constraints certainly influenced the dress code, but opting for the austere model of dress also signaled na- 
tional dedication and social consciousness. Hence even people who held high ranks or managerial positions would sometimes "dress down" and flaunt their informal dress. When reporters visited the Bedouin market in the southern town Beer Sheva, they encountered "a tall Jew, wearing khaki pants and a light blue shirt." Assuming he was a casual passer-by, they were much surprised to learn that the man was in fact the mayor of Beer Sheva. ${ }^{94}$ Even the manager of a luxurious hotel thus went among his elegantly-dressed visitors wearing a simple shirt with its sleeves rolledup. "Here the tie doesn't count," he stated, and was probably trying to refute the snobbish image attached to luxury hotels in 1950s Israel. ${ }^{95}$

A direct continuation of the pioneering style, the Israeli austere model of dress also played a nostalgic role within the emerging national culture. ${ }^{96}$ By the 1950s it was associated with long-time Israelis, and especially with local native Sabras, and therefore-as we shall see-could signify successful acculturation among new immigrants. After the foundation of the state, when Israeli society was dramatically changing due to mass immigration, and when most of the population continued to settle in cities and towns, the agricultural field and the Yishuv period were surrounded by nostalgic notions. Long-time Israelis tended to describe the pre-state era in idyllic terms, and to inaccurately ascribe a simple lifestyle to the whole Yishuv society, rather than to a small minority of pioneers. ${ }^{97}$ As one fashion columnist lamented in a daily newspaper in early 1951:

Indeed there was once a time, when the Yishuv not only adorned itself in its khaki clothes, but also took pride in this frugal and humble style ... but these days are gone and never to return. Khaki shorts were replaced by long, woolen pants, ironed according to the rules of elegance; whilst our fair sex is following fashion and even competing with Paris ... At present no one is willing to return to the khaki clothes of old, and even high-school girls would not give up their nylon stockings. ${ }^{98}$

As a matter of fact, the popularity of khaki shorts among growing segments of society increased after the foundation of the state. Urbanites in the Yishuv era were often keen followers of fashion, a tendency that continued among some women but actually decreased among Israeli men. Nylon stockings were indeed a coveted article during the years of 
scarcity and rationing, but silk stockings were worn by fashionable women during the Yishuv era as well. Nevertheless, and historical facts aside, as the austere model of dress now held a high status and epitomized the values of the hegemonic centralist ethos, it was covered with renewed admiration. Moreover, from the viewpoint of Israel's 1950s present, the Yishuv past was colored in nostalgic shades and the aspired-for simplicity was attributed to former days. Although at the time the pioneers' dress was implemented in reality only by a minority, it was now longingly regarded as a general symbol of the Yishuv era, a reminder of lost purity and innocence.

The austere model of dress also manifested and strengthened evolving notions of masculinity and femininity. Like the pioneers' dress before it, the austere style expressed unassuming, uncouth toughness. This may explain why this model of dress was adopted by more men than women. Rozin also suggests that women's marginal place in society made them less obligated and committed than men to the centralist ethos and its austere code. ${ }^{99}$ Indeed, dress patterns both in Revolutionary France and Fascist Italy reveal a similar division: men, politically central, were required to dress according to the ruling political ideals whereas women, politically marginal, were not limited to the same degree and enjoyed a greater "freedom of dress." 100

In Israel, as in other contemporary societies, men were put under pressure to avoid what was considered "excessive" male vanity. Men who took obvious care of their appearance were presented comically as effeminate. ${ }^{101}$ Since the 1940s, many middle class Israeli men adopted less formal dress, and the years of rationing might have enhanced this tendency. While women felt that the conditions of rationing limited their proper scope of dress, men were already required to embrace stylistic moderation and simplicity as an aesthetic choice, and therefore the poor material conditions of war and rationing could paradoxically "assist" them in achieving stylistic unfussiness. ${ }^{102}$

But what about female Sabras and other Israeli women who dressed according to the codes of the austere model? From the outset, Zionist ideology and culture-like most national movements-nurtured the image of the "new Jew" while the "new Jewess" remained marginal and vague. The same continued in Israel, where the Sabra image concentrated on the male native. To be sure, the image of the mythical male Sabra was complex and included some unclear elements and contradictions; but the 
mythical female Sabra was even less distinct and almost insignificant. Her image was based on a couple of stereotypes regarding her physical appearance, a general commitment to contribute to the national mission, and her passive role as the fighter's girlfriend, waiting for his return from the battlefield. ${ }^{103}$ Similarly, the female version of the austere model of dress looked like a slightly modified adaptation of the male version. The austere model of dress thus accentuated men's manliness, while toning down women's femininity.

So did the austere model, with its restrained vanity and tom-boyish qualities, empower Israeli women? Was the woman who dressed according to the austere model, namely more similar to men, closer to fulfilling the Zionist ideological notion about more equality between the sexes? ${ }^{104}$ If "dress equality" is practiced merely by making women's clothes more like men's, it might deny women the capacity to manipulate the gaze and use it for their own advantage. In the Israeli case, women who gave up fashion for ideological reasons and adopted the austere model of dress were fulfilling their national duties but probably paying not just an aesthetic price, but also yielding some of their potential power of choice, expression, and influence. ${ }^{105}$

Although the voluntary sacrifice advocated by Ben-Gurion's centralist ideal was fulfilled in practice only by a minority, the austere model of dress became a widespread costume in Israel, especially among men. It was identified with the country's hegemonic values and with its prestate pioneering heritage. It suited the local climate and the limiting economic conditions. It was regarded as an authentic, nostalgic, local dress, unifying visually the heterogeneous society of the young state. Former pioneers might have forsaken their ascetic lifestyle, but at the same time the wider Israeli public could indicate its loyalty to the centralist ethos by adopting the austere model of dress, with or without fulfilling other, and more demanding, pioneering commandments.

Thus the austere model of dress reflected both economic necessity and ideological choice. Although this style was inexpensive and affordable, it should be noted that it clearly differed from the dress worn by paupers. Photographs of the country's poor show them wearing shabby, tattered clothes, sometimes torn or patched. Often the size did not fit the wearers, and garments hung on their bodies like a sack. These clothes sometimes looked as if they were once rather smart but had been worn out by long over-use. Conversely, the austere model looked like a vol- 
untary ideological self-denial, an intentional anti-fashion. Even when it was actually chosen out of material necessity-, being less costly than smarter clothes, it enjoyed the advantage of signaling hegemonic power rather than economic weakness, and was therefore worn with pride, like a badge of honor, with a kind of haughty modesty. ${ }^{106}$

\section{NOTES}

1. For instance Dosh (1956), 19, 23, 34, 36, 38, 42, 55-56, 60, 65, 78, 116, 121, 129. On iconic figures representing the modern state, see Hobsbawm (2006), 7.

2. On ideal-types as helpful analytical tools for deciphering the tangled everyday experience see Bauman (2007), 24.

3. Quotation from Laisha, April 18, 1956. Photos by Fritz Cohen, 1951 - NPC: D544-086, D218-088. Photos from 1952 and 1954 - CZA: 1278596, 1278174. Geva newsreels, 1955 - SA: VT GE 07. Photos in Dvar hashavu'a, February 22, 1951, August 23, 1951, July 17, 1952. On Israeli hairstyles see Almog (2003), 86 , 89. And compare with communist China's palate of blue, green, or grey in Finnane (2008), 205.

4. Steele (2005a), vol. 2, 177, 181, 192.

5. Hobsbawm (2006), 287-288; Chenut (2005), 218, 252; Yahav (2003), 78.

6. Rosenthal (2006), 154.

7. Protestant Templar Germans (Tempelgesellschaft) settled in Palestine since the late nineteenth century.

8. Yahav (2003), 77; Raz (1996), 160. Also see "Pardon My Turkish", Forward, October 24, 2003.

9. For instance Hamodi'a, October 19, 1951. Illustration in Zmanim, September 1, 1954. Sketches of Ata hats, 1955 - SCA. Also see photo in Bamachaneh, June 10, 1954, and cartoon in Dosh (1956), 19.

10. Photo in Bamachaneh, May 31, 1951. Geva newsreels, 1952, 1954 - SA: VT GE 01, VT GE 07.

11. Dvar hashavu'a, October 6, 1949. Hedei hanegev, May 1952. Min ha'ir el hakfar, 4-5, August 1956. Geva newsreels, 1952 - SA: VT GE 01. 1950s white chemises - SCA. Ad in Ha'olam hazeh, April 15, 1954. Photo from 1949 - CZA: 1010020. Photo by Fritz Cohen, 1955, and photo from 1956 - NPC: D726-107, D448093. On various meanings of white clothes see Anderson (2009), 60.

12. Raz (1996), 150-151. Photos from 1950 - CZA: 1011645, 1011646, 11331123. Correspondence from 1950 - ISA: 47/c - 225/48. Poster from 1953 - CZA: KRA 1390. 1950s Ata clothes and 1955 designs - SCA.

13. Kolno'a, November 4, 1954. Cartoon in Haaretz, August 18, 1950. Photo from 1952 - CZA: 1278581. Poster from 1953 - CZA: KRA 1390. On the history of Ata see Bar Or (2009). 
14. Lagever, January 20, 1954.

15. James (2000), 9; Browne (2000).

16. Raz (1996), 47-51, 85-87, 122-123; Hason (1997), 19. On embroidery in Slavic folklore see Konenenko (2007), 66-67.

17. Paradoxically, during these very same years, when Yishuv pioneers were donning Russian folk items, rural Russian dress was used in Soviet propaganda to indicate stagnation, and traditional folk dress was presented as an object of necessary reform. See Gradskova (2007), 130.

18. Raz (1996), 136, 158-159. Photos from 1952, 1954 - CZA: 1278581, 1278165, 1278166. Photos in Dvar hashavu'a, August 2, 1951, September 4, 1952, October 1, 1952. 1950s election poster - PC: V1885-5. Also see Sport yisrael, November 25, 1951.

19. Gelber (1996), 453-454. Also see Sivan (1991).

20. Schor (1956), 48; Raz (1996), 160.

21. Radai (1956), 78-79. Dorot, October 20, 1949, 8-9. For a less idyllic view of the Sabra see Zmanim, September 27, 1954, October 1, 1954, October 6, 1954.

22. Shapira (1997), 174; Almog (1997).

23. Ma'ariv, August 10, 1949.

24. Shavit (1992b), 142-144; Raz (1996), 144. And compare with Zweiniger-Bargielowska (2002), 157, 180, 259; Eaton (2004), 124.

25. Zweiniger-Bargielowska, (2002), 50-51, 94-95; Mendes and de la Haye (1999), 111-112, 114; Tarrant (1994), 142, 144; Ewing (1992), 142-146.

26. Raz (1996), 105-109. Letter from April 25, 1949 - ISA, 47/c-43/223. And compare with Zweiniger-Bargielowska, (2002).

27. Raz (1996), 137-139. Photo from 1949 - ISA: 47/c-33/200. Lakol regulations, 1949 - ISA: 47/c-15/222. Production reports, 1950 - ISA: 47/c-29/223.

28. Raz (1996), 137. Compare with Stitziel (2005), 56-57, 71, 132; Stitziel (2008), 257.

29. Dvar hapo'elet, December 1951. Also see Haaretz, March 24, 1950.

30. Rozin (2005a), 58; Gross (1997), 138-139; Naor (2009), 63-105.

31. Gross (1995), 232-239; Gross (1997), 140, 142; Giladi (2002), 40-42.

32. Rozin (2005a), 58; Rozin (2008), 21-47, 58-59; Rozin (2005b), 273-290; Rozin (2002); Ben-Uzi (2008).

33. "Rationing" in Encyclopedia Britannica (2003); Osokina (2001), 198, 200-201. Also see Trentmann (2006), 12.

34. Compare with wartime clothes rationing in other countries: Osokina (2001), 197, 199; Guenther (2005), 28, 30, 131-137, 205, 212-232; Schallie (2007), 99-104; Veillon (2002), 40, 55; Ewing (1992), 145, 147; Hill (2004), 70-72. Also see Mee and Safronova (2003), 143-144.

35. Rozin (2008), 37-43; Rozin (2002), 97; Raz (1996), 140; Shavit (1992b), 142144. Haaretz, July 31, 1950.

36. Shavit, Goldstein, and Beer (1983), 252.

37. Penslar (2003).

38. Haaretz, July 31, 1950, August 15, 1950. Also see Ma'ariv, August 4, 1950. And 
compare with Stitziel (2008), 264.

39. Letter from December 25, 1949 - ISA, 47/c-33/200. Rationing poster, 1950 CZA: KRA 600.

40. Haaretz, July 31, 1950. Ma'ariv, August 4, 1950. See Rozin, 2006, 58-59. Compare with Zweiniger-Bargielowska (2002), 48-49, 96-97.

41. Rozin (2002), 97; Ma'ariv, August 6, 1950, August 7, 1950. Yediot aharonot, August 23, 1950. Dvar hashavu'a, October 12, 1950. Herut, October 6, 1950. Correspondence from 1949 - ISA: 47/c-33/200. Compare with Stitziel (2008), 258.

42. Yediot aharonot, January 6, 1950, August 23, 1950. Ashmoret, August 10, 1950, October 19, 1950. Ma'ariv, August 6, 1950, August 7, 1950, August 9, 1950. Ha'aretz, July 31, 1950. Haboker, August 21, 1950. Ben-Porat (1999), 124.

43. Rozin (2002), 97-98. Haboker, August 13, 1950, August 21, 1950, September 19, 1950. Yediot aharonot, August 23, 1950. Ma'ariv, September 5, 1950. Hador, October 12, 1952. Document from September 1950 - TAA: 1795/31. Report from 1950 - ISA: 47/c-29/201. Correspondence from 1950 - ISA: 47/c-34/222, 47/c-45/223. Correspondence from 1951 - ISA: 47/c-36/222. Geve newsreels, 1953, 1954, 1956 - SA: VT GE 04, VT GE 05, VT GE 07, VT GE 08.

44. Haisha bamedinah, September 1950. And compare with Rozin (2006), 65-66.

45. Rozin (2006), 61-64; Rozin (2008), 35-37, 44-46, 61-65, 78, 192-193. Photo in Dvar hashavu'a, October 19, 1950. And compare with black markets in wartime and post-war Germany and Britain: Guenther (2005), 229-232; Stitziel (2008), 264; Zweiniger-Bargielowska (2002), 157, 177, 259; Kynaston (2007), 111.

46. Haboker, July 6, 1951, July 13, 1951. Ma'ariv, July 9, 1951. Letters from 1950 - ISA: 47/c-31/222, ISA: 47/c-33/22. Letter from 1950 - TAA, 1844/31. And compare with Zweiniger-Bargielowska (2002), 155, 157.

47. Letters from 1950 - ISA: 47/c-34/206, 47/c-31/222, 47/c-36/222, 47/c35/222. And compare with Stitziel (2008), 265, 272-273.

48. Letters from 1950 - ISA: 47/c-36/222.

49. Letters from 1950 - ISA: 47/c-31/222.

50. Ads in Ma'ariv, October 7, 1949, November 17, 1950; Jerusalem Post, July 1, 1949, July 8, 1951; Haaretz, August 14, 1950, October 6, 1950.

51. Jerusalem Post, July 5, 1951. On Metzkin see Raz (1996), 80, 115, 147-148.

52. Ad in Ma'ariv, August 15, 1951.

53. Rozin (2002), 99; Raz (1996), 142. Dvar hashavu'a, December 20, 1951. Photo from 1951 - NPC: D720-091. Election Poster from 1951 - PC: V2158-7.

54. Raz (1996), 142. Dvar hashavu'a, December 20, 1951. Dvar hapo'elet, December 1951.

55. Rozin (2006), 61; Rozin (2008), 31; Rozin (2005a), 174. And compare with Kynaston (2007), 225; Stitziel (2008), 256, 265, 267; Lewis (2008), 3; Smulyan (2007), 59. On Jewish humor as a way of dealing with hardship and suffering see Kerman (1995), 181; Penslar (2007), 175, 185.

56. For instance Haboker, August 10, 1950. Dvar hashavu'a, March 1, 1951. Front cover of satirical pamphlet from 1950 - NNL. Cartoons in Ashmoret, August 10, 1950; Dvar hashavu'a, May 24, 1951; Tafrit, September 1950, December 1950; 
Ma'ariv, July 15, 1949, August 18, 1950, October 11, 1950; Bamachaneh, June 2, 1949. Jokes in Dvar hashavu'a, August 10, 1950, August 17, 1950, September 19, 1950.

57. Cartoon in Dvar hashavu'a, August 10, 1950.

58. Cartoon in Dvar hashavu'a, August 10, 1950.

59. Haaretz, August 23, 1951.

60. Dvar hashavu'a, August 17, 1950. Ministry of Supply and Rationing list, September 1950 - TAA, 1795/31. Also see Dvar hashavu'a, May 24, 1951.

61. Dvar hashavu'a, April 5, 1951.

62. Zidon (1951), 35. Also see pages 47, 109.

63. Photos by Fritz Cohen and Teddy Brauner, 1950 - NPC: D140-126, D720-110, D720-102, D720-101. On the history of mannequins see Ganeva (2008), 153154. On humor in advertising see Gulas and Weinberger (2006).

64. Raz (1996), 142. Yediot aharonot, February 26, 1951, October 17, 1952, July 23, 1953. After The General Zionists, a political party supporting a freer market, won many votes in the general elections and joined the coalition government, the economic policy was changed in 1952 - see Rozin (2008), 130-196; Ben-Uzi (2008). Rationing was formally cancelled in 1959.

65. Alonekh, February 1953. Also see ad in Zmanim, December 27, 1953. And see Esperdy (2008), 151, 179-180.

66. For instance Jerusalem Post, December 12, 1952. Yediot hitachadut baalei hakolno'a beyisrael, August 18, 1953. Almog (1997), 332-334.

67. Ma'ariv, July 23, 1954. Haaretz, January 6, 1954. Yediot aharonot, February 26, 1954. Election poster from 1955 - PC: V2156-2(13).

68. Quoted by Segev (1984), 299. Also see Rozin (2008), 78.

69. Alexander (1992); Lissak (1998), 41-42.

70. Rozin (2005a), 158-159; Rozin (2006), 52, 56-57; Rozin (2008), 23-24. On attitudes toward luxury in the Yishuv see Helman (2010), 91.

71. Government poster from 1950 - CZA, KRA 600. Letter from 1950 - ISA: 47/c3/159. Haaretz, August 24, 1950, January 23, 1951. Rozin (2002), 99, 103.

72. Details on the notion "mamlakhtiyut", its origins and development, see Kedar (2002).

73. Dowty (1995), 36-37; Don-Yehiya (1995), 176, 180. On the characteristics of the Zionist "New Jew" see Shapira (1996), 427-441; Segev (1984), 277.

74. Dowty (1995), 37; Alatout (2008), 44; Bareli (1999), 25-27, 36-37.

75. Dowty (2001), 5-64.

76. Drori (2000), 30, 32.

77. Gelber (1996), 450-451; Ben-Avram and Near (1994).

78. Near (1992a), 116-125; Zachor (2007), 137.

79. Bareli (1999), 38-39; Zachor (2007), 153-155; Rozin (2005a), 188; Rozin (2008), 136-139, 191-195; Ben-Porat (1999), 113-114; Lissak (1998), 38, 53-54; Giladi (2002), 60; Gelber (1996), 453.

80. Gramsci (1997), 15; Lears (1985), 571-575; Hall (1979), 332-334; Hebdige (1993), 366. 
81. Campbell (1994a), 44-48, 55. Also see Campbell (1994b), 43, 46.

82. Helman (2003), 81-83.

83. Almog (1997), 132-135, 326-328. On the looks of the ideal man in European nationalism see Mosse (1985), 31.

84. On this double negation in Socialist Zionism, see Peled (2002), 28-29.

85. Simmel (1997), 195-196; Wilson (2003), 3, 5, 12-13; Entwistle (2003), 48; Davis (1992), 161 n. 2; Lind and Roach-Higgins (1985), 184.

86. Compare with Berger (1991).

87. Giladi and Shwartz (2001), 11-13; Helman (2010), 150-154.

88. Geva newsreels, 1951-1956 - SA: VT GE 01, VT GE 03, VT GE 07, VT GE 08. Dvar hashavu'a, April 10, 1950. Jerusalem Post, July 15, 1952. Davar, September 30, 1955. And compare with Maynard (1994), 171-173, 176; Chen (2001), 153; Stern (2004), 52-53.

89. Compare with Berger (1991).

90. Haisha bamedinah, November 1949. Ha'olam hazeh, March 22, 1956. Photos in Dvar hashavu'a, October 25, 1951; Hedei hanegev, August 1952.

91. Letter from October 20, 1950 - ISA: 47/c-223/38.

92. Letter from - ISA: 47/c-200/33.

93. Haisha bamedinah, November 1949.

94. Matzpen, September 15, 1954.

95. Yediot aharonot, September 13, 1951. On luxury hotels and their image see $\mathrm{Ha}$ dor, May 20, 1955. Al hamishmar, July 3, 1955. Herut, August 24, 1955. Davar, September 7, 1955. Haaretz, June 12, 1955, September 16, 1955, August 3, 1956. Also see Segev (1984), 272.

96. Compare with the cultural role of the Australian "bush" costume: Maynard (1994), 159-164, 170-180.

97. Shavit (1992a), 70; Miron (2001), 177.

98. Yediot aharonot, February 26, 1951.

99. Rozin (2005a), 188; Rozin (2008), 43.

100. Hunt (1998), 227-228, 231, 235-236, 241; Gori (2004), 172. Also see Shinar (2000), 383.

101. Bradley (2007), 25; Davis (1992), 42. Cartoons in Ashmoret, September 1, 1949, May 4, 1950. Bamachaneh, June 21, 1951.

102. Raz (1996), 143, 159-160. And compare with Mendes and de la Haye (1999), 114-115; Zweiniger-Bargielowska (2002), 91-93; Maynard (1994), 171-173.

103. Horowitz (1993), 81-82. Also see Bernstein (2008), 36-41. And compare with Finnane (2008), 203.

104. Elboim-Dror (1993), 185-193.

105. Compare with Mattingly (2002), 54, 140, 143. Also see Pinker (2004), 429; Young (1993), 273.

106. Cartoon and illustration in Herut, February 22, 1952, January 13, 1956. Cartoons in Ashmoret, December 29, 1949, March 8, 1951. Photos in Ashmoret, March 29, 1951, April 26, 1951. Photo in Dvar hashavu'a, September 25, 1952. Geva newsreels, 1954 - SA: VT GE 05. 